\title{
Induction of Direct Shoot Organogenesis from Shoot Tip Explants of an Ornamental Aquatic Plant, Cryptocoryne wendtii
}

\author{
Sutha KLAOCHEED ${ }^{1, *}$, Wanna JEHSU ${ }^{2}$, \\ Wanwilai CHOOJUN ${ }^{2}$, Kanchit THAMMASIRI ${ }^{3}$, \\ Somporn PRASERTSONGSKUN ${ }^{4}$ and Suphat RITTIRAT ${ }^{5}$
}

\author{
${ }^{1}$ Department of Technology and Industries, Faculty of Science and Technology, \\ Prince of Songkla University, Pattani Campus, Pattani 94000, Thailand \\ ${ }^{2}$ Program in Biology, Faculty of Science and Technology, Nakhon Si Thammarat Rajabhat University, \\ Nakhon Si Thammarat 80280, Thailand \\ ${ }^{3}$ Department of Plant Science, Faculty of Science, Mahidol University, Bangkok 10400, Thailand \\ ${ }^{4}$ Department of Science, Faculty of Science and Technology, Prince of Songkla University, \\ Pattani Campus, Pattani 94000, Thailand \\ ${ }^{5}$ Faculty of Science and Technology, Nakhon Si Thammarat Rajabhat University, \\ Nakhon Si Thammarat 80280, Thailand
}

('Corresponding author's e-mail: sutha.psu@gmail.com)

Received: 26 March 2017, Revised: 13 February 2018, Accepted: 26 March 2018

\begin{abstract}
Cryptocoryne wendtii is an important amphibious species with a wide range of foliage colors. Although it has a high market demand, the natural propagation of its aquatic species is limited due to the limited production on the number of plants with a long cultivation period, disease, and the requirement for a large space for propagation. Thus, we studied the effects of the plant growth regulators and their concentrations on the induction of direct shoot organogenesis from shoot tip explants of Cryptocoryne wendtii. The shoot tips were sterilized on its surface using $8 \%$ Clorox ${ }^{\circledR}(5.25 \%$ sodium hypochlorite, $\mathrm{NaOCl}$ ) for 15 min followed by rinsing them three times with sterile distilled water. They were again sterilized on the surface for another $4 \%$ Clorox ${ }^{\circledR}(5.25 \%$ sodium hypochlorite, $\mathrm{NaOCl})$ for 5 min. Cytokinins played a crucial role in direct shoot organogenesis. Direct shoot organogenesis from shoot tip explants was promoted by incubating these explants on Murashige and Skoog (MS) medium [1] in the presence of two different cytokinins [6-benzyl-aminopurine (BAP) or Kinetin (Kin)], each provided at four different levels. Direct shoot organogenesis was induced in both explants. Shooting occurred $100 \%$ from in vitro shoot tip explants, which was cultured on MS medium and supplemented with $3.0 \mathrm{mg} / \mathrm{l}$ BAP. This was significantly different from the other treatments with the highest number of 16.20 shoots per explant and number of leaves at 72.40 leaves per explant after 60 days of culture. Individual shoots, aseptically excised, which produced normal roots within 45 days on the MS medium supplemented with $\alpha$-Naphthaleneacetic acid (NAA). The highest number of roots per shoot and the longest roots were obtained on MS medium supplemented with $1.0 \mathrm{mg} / 1$ NAA (100\% rooting, which was an average of 36 roots per plantlet and root length at $26.02 \mathrm{~mm}$ ). Rooted plantlets were successfully hardened and established in pots containing a mixture of organic soil and sand (1:1) overlaid with tap water under greenhouse conditions at $90 \%$ survival. This complete study has successfully outlined a rapid, high frequency direct shoot organogenesis induction of an ornamental aquatic plant, Cryptocoryne wendtii from shoot tip explants inclusive of shoot proliferation, rooting and acclimatization. The present in vitro propagation protocol would facilitate an alternative method for rapid, large-scale production and germplasm preservation of this important endangered species $C$. wendtii.
\end{abstract}

Keywords: Tissue culture, plant growth regulators, acclimatization, organogenesis 
http://wjst.wu.ac.th

\section{Introduction}

The Cryptocoryne (water trumpet) is an important genus of the family Araceae, comprising about 50 - 60 species of aquatic monocot plants. Most of the Cryptocoryne species are native of Southeast Asia, which grow in either submerged or emerged state [2]. Cryptocoryne species are also popular aquarium plants [3]. Additionally, Cryptocoryne wendtii, which has a high market demand, is an important amphibious species with a wide range of foliage colors (green to brown). However, natural propagation of the aquatic species is limited due to the small production of the number of plants with a long cultivation period, disease, and the requirement for a large space for propagation [4]. The collection of plant materials from the wild resources can be reduced or prevented with the production of clonal propagated plants. Thus, micropropagation seems to be the most promising method for a large-scale production of plantlets for the markets. The other advantages of clonal propagation over conventional propagation techniques include: progeny are true to type, multiplication is rapid, and production cost is low.

Developing a micropropagation system with a high multiplication rate is an important asexual method for production of healthy clonal plants. Shoot tip explants with fully exposed and broad preexisting meristems have high regeneration potential to rapidly form multiple shoots in a reduced number of step in which the protocol is genotype independent. Moreover, plant regeneration is direct, i.e. without a callus phase from the culture of apical meristems, and thus plants produced risk less somaclonal variation [5]. Tissue culture system for Cryptocoryne species have been reported that utilize shoot tips [6,7]; single-node explants [8] and rhizomes [9]. However, there has been no report on the direct shoot organogenesis of Cryptocoryne wendtii.

The objectives of the current study were to test the effectiveness of cytokinins for the induction of Cryptocoryne wendtii direct shoot organogenesis, and to develop an effective protocol for the regeneration of Cryptocoryne wendtii from shoot tip explants. Such a protocol would allow for a largescale propagation to meet the commercial needs and to directly conserve this threatened Cryptocoryne species by reducing wild collection.

\section{Materials and methods}

\section{Plant materials, explants preparation and sterilization}

Young plantlets of $C$. wendtii were obtained from the Aquatic Plant Center Co., Ltd., Thailand. Shoot tips were excised from the mother plants and were washed thoroughly under running tap water. The shoot tips were sterilized on the surface using $8 \%$ Clorox ${ }^{\circledR}(5.25 \%$ sodium hypochlorite, $\mathrm{NaOCl})$ for 15 min followed by rinsing them three times with sterile distilled water. They were again sterilized on the surface for another $4 \%$ Clorox ${ }^{\circledR}(5.25 \% \mathrm{NaOCl})$ and 2 - 3 drops of Tween 20 per $100 \mathrm{ml}$ solution for 5 min. The treated plantlets were washed three times with sterile distilled water to remove traces of disinfectant. The surface-sterilized shoot tips with one or two leaf primordia were selected as explants for direct shoot organogenesis. The shoot tips, segments of $0.5-1 \mathrm{~cm}$ in length were excised aseptically and inoculated into bottles containing Murashige and Skoog (MS) medium [1] without plant growth regulator for 7 days.

\section{Culture conditions}

All media used for the present study were based on MS medium supplemented with $3 \%$ (w/v) sucrose and $0.76 \%(\mathrm{w} / \mathrm{v})$ agar (commercial grade). The $\mathrm{pH}$ of the media was adjusted to 5.7 with $1 \mathrm{~N}$ $\mathrm{KOH}$ or $1 \mathrm{~N} \mathrm{HCl}$ prior to autoclaving for $15 \mathrm{~min}$ at $121^{\circ} \mathrm{C}$. All cultures were maintained at $25 \pm 2{ }^{\circ} \mathrm{C}$ air temperatures under a $16 \mathrm{~h}$ photoperiod with light supplied by cool-white fluorescent lamps at an intensity of $10 \mu \mathrm{mol} \mathrm{m} \mathrm{m}^{-2}$ photosynthetic photon flux density (PPFD). Plant materials were stored in glass-capped culture jars (115 ml capacity) each containing $25 \mathrm{ml}$ of medium.

Effects of cytokinins on direct shoot organogenesis induction from shoot tip explants in vitro

Shoot tip explants $(0.5-1 \mathrm{~cm}$ in length) of 7 days old in vitro were cultured on MS medium supplemented with 6-benzyl-aminopurine (BAP) and Kinetin (Kin) at different concentrations (0, 0.5, 1.0, 
http://wjst.wu.ac.th

2.0 and $3.0 \mathrm{mg} / \mathrm{l}$ ) either singly. The percentage of shooting, number of shoots per explant, number of leaves, leaf length $(\mathrm{mm})$ and leaf width $(\mathrm{mm})$ were recorded and compared statistically after 60 days of culture. The plant growth regulators-free MS medium was used as control.

\section{Effects of NAA on root induction in vitro}

For root induction, in vitro regenerated shoots measuring $3-4 \mathrm{~cm}$ in length with two pairs of fully expanded leaves were cultured on MS medium without growth hormones or supplemented with $\alpha$-Naphthaleneacetic acid (NAA) at different concentrations $(0.5,1.0$ and $1.5 \mathrm{mg} / \mathrm{l})$ alone. The percentage of rooting, number of roots per explant and root length $(\mathrm{mm})$ were recorded and compared statistically after 45 days of culture.

\section{Greenhouse Acclimatization}

After 45 days of culture, in vitro rooted plantlets of $C$. wendtii were gently taken out from rooting medium and washed carefully with a soft brush in tap water to remove the adhering agar-agar with plant tissue. The plantlets were then transplanted into plastic pots containing a mixture of organic soil and sand (1:1) overlaid with tap water under greenhouse conditions. The plantlets were grown in the greenhouse with $80-90 \%$ relative humidity and about $12 \mathrm{~h}$ photoperiod, $300-400 \mu \mathrm{mol} \mathrm{m} \mathrm{m}^{-2} \mathrm{~s}^{-1}$ photosynthetic photon flux density (PPFD) (shaded sunlight) and $28 \pm 1$ to $24 \pm 1{ }^{\circ} \mathrm{C}$ day/night temperature. The percentage of plantlet survival was recorded 60 days of acclimatization.

\section{Experimental design and statistical analysis}

All the experiments were conducted in a completely randomized design (CRD) with 5 replicates per treatment. In addition, the experiments were repeated three times. The results were expressed as mean \pm SE of three experiments. The data were analyzed by ANOVA using SPSS version 20.0 and the mean values were separated using Duncan's multiple range test (DMRT) at a $5 \%$ probability level.

\section{Results and discussion}

Effects of cytokinins on direct shoot organogenesis induction from shoot tip explants in vitro

Tissue culture techniques are used extensively for growing plants commercially. This process involves growth of new plants from small pieces of plant tissue in a nutrient medium, sterile conditions. Under sterile conditions, plant can be induced to rapidly produce new shoots which can be subdivided to produce more plants [10]. A successful micropropagation protocol proceeds through a series of stages, each with a specific set of requirements. These are (i) initiation of aseptic cultures, (ii) shoot multiplication, (iii) rooting of macro shoots and (iv) hardening and field transfer of tissue culture raised plants [11]. For initiation of aseptic cultures, a thorough knowledge of the physiological status and the susceptibility of the plant species to different pathological contaminants are required.

Micropropagation offers a viable alternative for conventional methods because it can also be used as a complimentary strategy for conservation and utilization of genetic resources. Further, in vitro plant regeneration is an easy and economical way for obtaining a large number of consistently uniform and true-to-type plants within a short span of time [12].

Regeneration potential of shoot tip explants of $C$. wendtii was explored on MS medium supplemented with various plant growth regulators (PGRs) (BAP: 0, 0.5, 1.0, 2.0 and 3.0 mg/l; Kin: 0.5, 1.0, 2.0 and $3.0 \mathrm{mg} / \mathrm{l}$ ) and the results were summarized in Table 1. Shoot tip explants cultured on MS media fortified with cytokinins alone induced multiple shoots without an intervening callus phase. All the concentrations of BAP and Kin facilitated shoot bud differentiation, but BAP being more efficient than Kin in term of number of shoots per explant and number of leaves. The number of shoots per explant increased with increasing concentration of BAP up to an optimal level of $3.0 \mathrm{mg} / \mathrm{l}$ in medium (Table 1). Among the various concentrations of BAP and Kin tested, $3.0 \mathrm{mg} / \mathrm{l} \mathrm{BAP}$ showed the highest number of shoots per explant $(16.20 \pm 1.02)$ and number of leaves $(72.40 \pm 4.80)$ with significantly different from other treatments (Table 1 and Figure 1B). These findings demonstrated that $3.0 \mathrm{mg} / \mathrm{l} \mathrm{BAP}$ was efficient 
http://wjst.wu.ac.th

for shoot multiplication. Two months after treatments, few shoots were still observed on shoot clusters cultured on the cytokinins (BAP, Kin) contained media.

In case of Kin, maximum percent response was recorded in medium supplemented with $2.0 \mathrm{mg} / \mathrm{l}$ in shoot tip explants. There was no significant difference in shoot development between the treatments with Kin at $0.5,1.0,2.0$ and $3.0 \mathrm{mg} / \mathrm{l}$ (Table 1). In case of Kin, the highest number of shoots per explant $(6.80 \pm 0.58$ shoots), number of leaves $(33.40 \pm 1.69$ leaves $)$, leaf length $(20.69 \pm 0.74 \mathrm{~mm})$ and leaf width $(5.11 \pm 0.22 \mathrm{~mm})$ was achieved from shoot tip explants on MS medium containing $2.0 \mathrm{mg} / \mathrm{Kin}$ (Table 1 and Figure 1C).

The lowest mean number of shoots multiplied per single shoot tip explant $(2.50 \pm 0.63$ shoots $)$ developed in the absence of plant growth regulators (Figure 1A). The leaves of the adventitious shoots were healthy with green to brown color and did not show any sign of vitrification. No difference in the morphology of the shoots was observed between the shoot tip explants under the absence of growth regulators, BAP and Kin treatments.

This response could be explained by the endogenous hormone in explants of which balance would probably be in favor of cytokinins. However, the mean number of shoots per explant varied significantly among the different types and concentrations of cytokinins tested. BAP produced superior responses in shoot regeneration than Kin. This might be due to its concentration in stimulating the tissue to metabolize the endogenous hormones and induce the production of endogenous hormones for the induction of multiple shoots. It is well known that cytokinins stimulate plant cell division and participate in the release of lateral bud dormancy, in the induction of adventitious bud formation, in the growth of lateral buds and in the cell cycle control [13]. Several reports have verified the superiority of BAP in enhancing bud induction at concentrations ranging from 1.0 - $5.0 \mathrm{mg} / \mathrm{l}[14]$.

The results of this study indicated that plant growth regulator supplementation is essential for the micropropagation of $C$. wendtii. The effectiveness of BAP in shoot bud differentiation has been documented in the number of plants [15,7]. Wang et al. [16] reported that the presence of $3.0 \mathrm{mg} / \mathrm{l} \mathrm{BAP}$ in the medium effectively increased the number of regenerated shoots of Scipus robustus an emergent hydrophyte. Shoot regeneration using BAP or Kin has been observed in Ipomoea batatas [17]; Aconitum violaceum [18]. Cytokinins (BAP) have been reported to induce the development of axillary buds and adventitious buds through decreasing apical dominance [19].

C. wendtii, an important plant in the ornamental aquatic industry, was investigated in this study with a goal to establish an efficient micropropagation procedure through high frequency shoot proliferation. Direct shoot organogenesis has been the main method of micropropagation for ornamental plants as indirect organogenesis through a callus phase often resulted in somaclonal variation as observed in Dieffenbachia [20]. Direct shoot organogenesis; however, can be limited by the availability of preexisting meristems on the explants and a low multiplication rate. In this study, the determination of the most ideal type and concentration of PGRs as medium constituents was investigated since PGRs have been considered as key factors governing the success of shoot induction and proliferation in many plant species. 

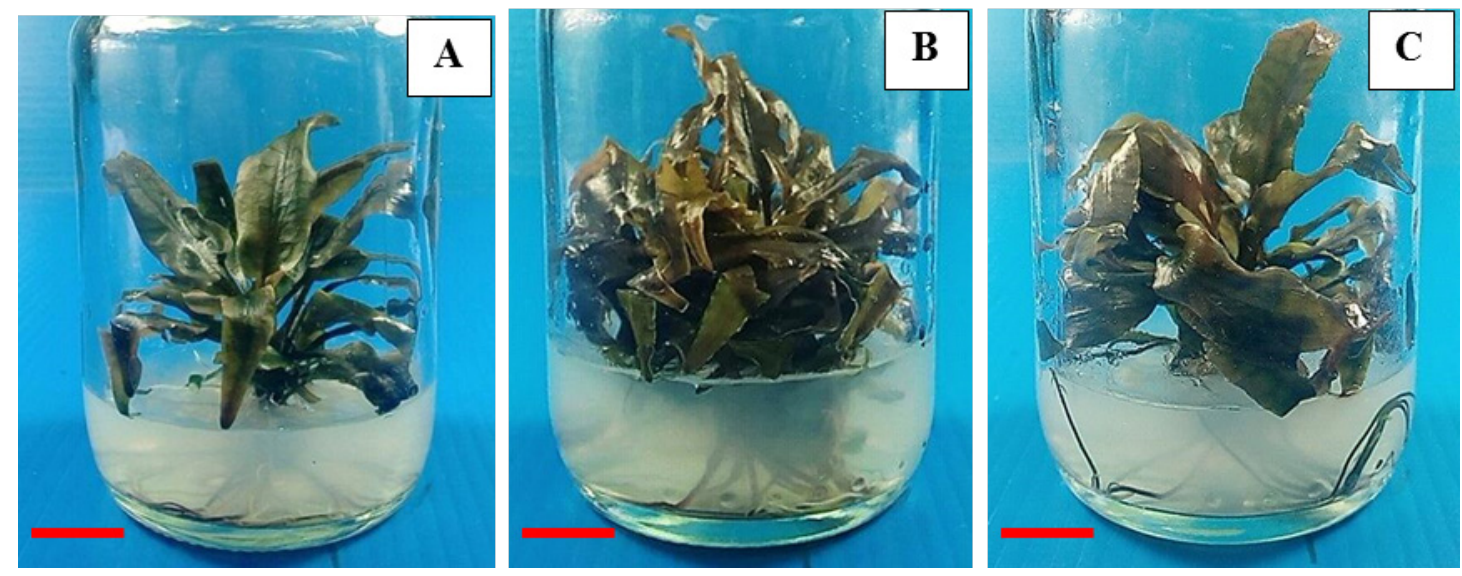

Figure 1 (A) In vitro propagation of Cryptocoryne wendtii; multiple shoots formation from a single shoot tip explants after 60 days cultured on agar-gelled MS medium supplemented with (A) Control, (B) $3.0 \mathrm{mg} / 1 \mathrm{BAP}$ and (C) $2.0 \mathrm{mg} / 1 \mathrm{Kin}$. (Scale bar $=1 \mathrm{~cm}$ ).

Table 1 Effects of cytokinins on direct shoot organogenesis induction from shoot tip explants in vitro after 60 days of culture

\begin{tabular}{|c|c|c|c|c|c|c|}
\hline \multicolumn{2}{|c|}{$\begin{array}{l}\text { PGRs } \\
(\mathrm{mg} / \mathrm{l})\end{array}$} & \multirow{2}{*}{$\begin{array}{c}\text { Shooting } \\
(\%)\end{array}$} & \multirow{2}{*}{$\begin{array}{c}\text { No. of shoots } \\
\text { per explant } \\
(\text { mean } \pm \text { SE) }\end{array}$} & \multirow{2}{*}{$\begin{array}{l}\text { No. of leaves } \\
(\text { mean } \pm \text { SE })^{a}\end{array}$} & \multirow{2}{*}{$\begin{array}{l}\text { Leaf length } \\
\quad(\mathrm{mm}) \\
(\operatorname{mean} \pm \mathrm{SE})^{\mathrm{a}}\end{array}$} & \multirow{2}{*}{$\begin{array}{c}\text { Leaf width } \\
\quad(\mathrm{mm}) \\
(\operatorname{mean} \pm \mathrm{SE})^{\mathrm{a}}\end{array}$} \\
\hline BAP & Kin & & & & & \\
\hline 0 & 0 & $60.00^{b}$ & $2.50 \pm 0.63^{\mathrm{e}}$ & $33.00 \pm 7.26^{\mathrm{c}}$ & $18.70 \pm 0.58^{\mathrm{bc}}$ & $4.50 \pm 0.14^{b}$ \\
\hline 0.5 & - & $100.00^{\mathrm{a}}$ & $8.40 \pm 1.12^{\mathrm{bcd}}$ & $41.00 \pm 4.89^{\mathrm{c}}$ & $16.23 \pm 0.55^{\mathrm{d}}$ & $4.01 \pm 0.13^{\mathrm{cd}}$ \\
\hline 1.0 & - & $100.00^{\mathrm{a}}$ & $9.20 \pm 1.02^{\mathrm{bc}}$ & $40.40 \pm 4.20^{\mathrm{c}}$ & $17.77 \pm 0.56^{\mathrm{c}}$ & $4.06 \pm 0.13^{\mathrm{cd}}$ \\
\hline 2.0 & - & $100.00^{\mathrm{a}}$ & $11.00 \pm 1.05^{\mathrm{b}}$ & $57.80 \pm 7.04^{\mathrm{b}}$ & $15.66 \pm 0.40^{\mathrm{d}}$ & $3.72 \pm 0.11^{\mathrm{de}}$ \\
\hline 3.0 & - & $100.00^{\mathrm{a}}$ & $16.20 \pm 1.02^{\mathrm{a}}$ & $72.40 \pm 4.80^{\mathrm{a}}$ & $15.82 \pm 0.31^{\mathrm{d}}$ & $3.40 \pm 0.09^{\mathrm{e}}$ \\
\hline- & 0.5 & $100.00^{\mathrm{a}}$ & $6.60 \pm 0.40^{\mathrm{cd}}$ & $29.80 \pm 1.98^{c}$ & $20.11 \pm 0.67^{\mathrm{ab}}$ & $4.01 \pm 0.15^{\mathrm{cd}}$ \\
\hline - & 1.0 & $100.00^{\mathrm{a}}$ & $6.60 \pm 0.24^{\text {cd }}$ & $30.20 \pm 2.91^{c}$ & $20.75 \pm 0.64^{\mathrm{a}}$ & $4.31 \pm 0.16^{\mathrm{bc}}$ \\
\hline- & 2.0 & $100.00^{\mathrm{a}}$ & $6.80 \pm 0.58^{\mathrm{cd}}$ & $33.40 \pm 1.69^{\mathrm{c}}$ & $20.69 \pm 0.74^{\mathrm{a}}$ & $5.11 \pm 0.22^{\mathrm{a}}$ \\
\hline- & 3.0 & $100.00^{\mathrm{a}}$ & $6.40 \pm 1.40^{\mathrm{cd}}$ & $33.20 \pm 1.93^{\mathrm{c}}$ & $20.05 \pm 0.61^{\mathrm{ab}}$ & $4.25 \pm 0.13^{\mathrm{bc}}$ \\
\hline
\end{tabular}

Similar letters within the same columns mean no significant difference at $\mathrm{P} \leq 0.05$ by DMRT.

${ }^{\mathrm{a}}$ Values represent means \pm standard error. 
http://wjst.wu.ac.th

\section{Effects of NAA on root induction in vitro}

Regenerated shoots (15-20 mm in length) derived from the $3.0 \mathrm{mg} / \mathrm{l} \mathrm{BAP}$ treatment of the previous experiment were excised from the explants and cultured on growth regulator-free MS. MS medium containing $0,0.5,1.0$ or $1.5 \mathrm{mg} / \mathrm{l} \mathrm{NAA}$ were tested for their influence on adventitious rooting under in vitro conditions. For NAA supplements, increased concentration induced greater root production throughout the range evaluated with the three highest concentrations which were significantly different from the control treatment. Long, healthy roots were observed in $100 \%$ of shoots on MS medium supplemented with $1.0 \mathrm{mg} / 1$ NAA after 45 days of implantation (Table 2 and Figure 2C). Further increase in concentration of NAA $(1.5 \mathrm{mg} / \mathrm{l})$ decreased the root formation percentage $(89.00 \%)$, number of roots per explant $(22.50 \pm 2.90$ roots) and root length $(24.05 \pm 0.48 \mathrm{~mm})$ (Table 2 and Figure 2D). For in vitro rooting, shoots subjected to $1.0 \mathrm{mg} / \mathrm{l} \mathrm{NAA}$ treatment produced an average of $36.00 \pm 4.63$ roots and root length at $26.02 \pm 0.70 \mathrm{~mm}$ was significantly different from other treatments (Table 2 and Figure 2C). The use of NAA in enhancing the root formation has also been observed in Cryptocoryne beckettii and Cryptocoryne bogneri [21]; Kinnow [22] and Hippeastrum johnsonii [23].

In the present investigation, the regeneration capacity of $C$. wendtii roots was significantly enhanced with the addition of NAA to MS medium. These results were the same as Oh et al. [24], who reported that a lower concentration of auxin was optimal for rooting.
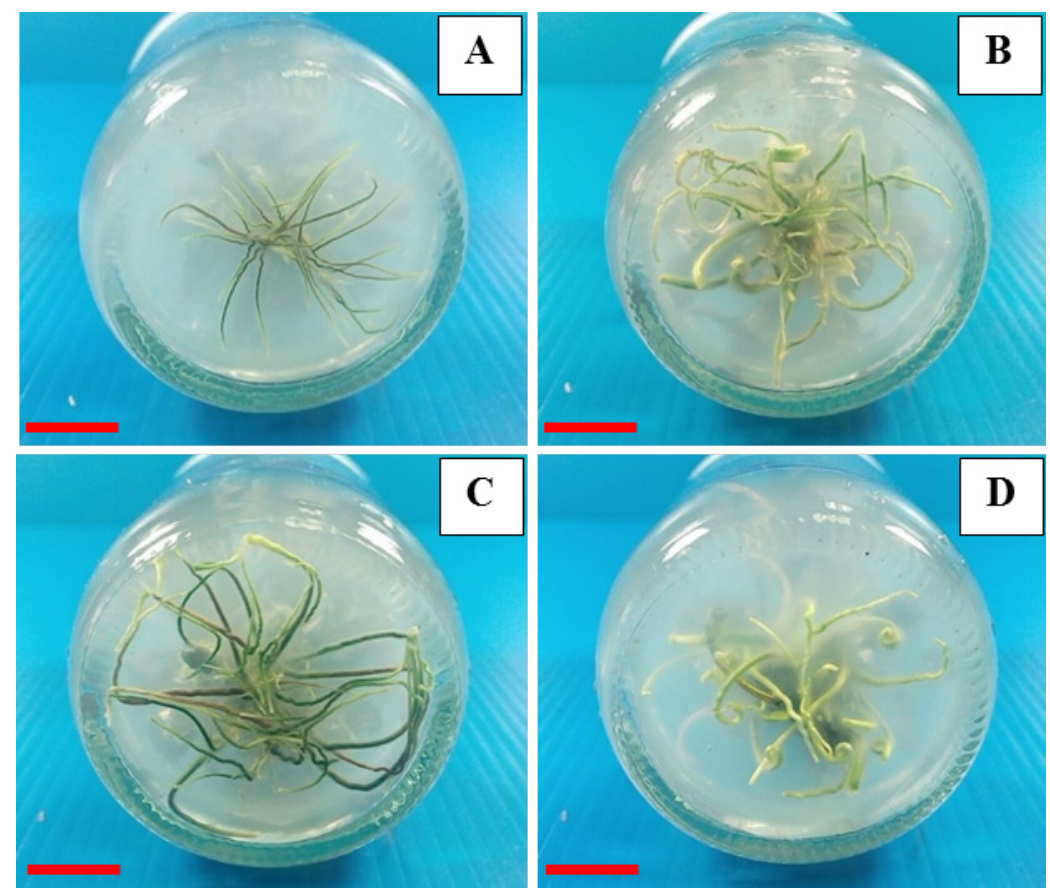

Figure 2 Effects of NAA on in vitro rooting of Cryptocoryne wendtii adventitious shoots after 45 days of culture on MS medium containing: (A) $0 \mathrm{mg} / \mathrm{l} \mathrm{NAA}$, (B) $0.5 \mathrm{mg} / \mathrm{l} \mathrm{NAA}$, (C) $1.0 \mathrm{mg} / \mathrm{l} \mathrm{NAA}$ and (D) $1.5 \mathrm{mg} / 1 \mathrm{NAA}$. (Scale bar $=1 \mathrm{~cm}$ ) 
http://wjst.wu.ac.th

Table 2 Effects of NAA on root induction of in vitro Cryptocoryne wendtii after 45 days of culture

\begin{tabular}{cccc}
\hline $\begin{array}{c}\text { NAA } \\
(\mathbf{m g} / \mathbf{l})\end{array}$ & $\begin{array}{c}\text { Rooting } \\
(\mathbf{\%})\end{array}$ & $\begin{array}{c}\text { No. roots per explant } \\
(\mathbf{m e a n} \pm \mathbf{S E})^{\mathbf{a}}\end{array}$ & $\begin{array}{c}\text { Root length }(\mathbf{m m}) \\
(\mathbf{m e a n} \pm \mathbf{S E})^{\mathbf{a}}\end{array}$ \\
\hline 0 & $70.00^{\mathrm{c}}$ & $16.90 \pm 1.65^{\mathrm{c}}$ & $13.91 \pm 0.68^{\mathrm{d}}$ \\
0.5 & $100.00^{\mathrm{a}}$ & $31.90 \pm 4.01^{\mathrm{ab}}$ & $18.60 \pm 0.53^{\mathrm{c}}$ \\
1.0 & $100.00^{\mathrm{a}}$ & $36.00 \pm 4.63^{\mathrm{a}}$ & $26.02 \pm 0.70^{\mathrm{a}}$ \\
1.5 & $89.00^{\mathrm{b}}$ & $22.50 \pm 2.90^{\mathrm{bc}}$ & $24.05 \pm 0.48^{\mathrm{b}}$ \\
\hline
\end{tabular}

Similar letters within the same columns mean no significant difference at $\mathrm{P} \leq 0.05$ by DMRT.

${ }^{a}$ Values represent means \pm standard error.

\section{Greenhouse acclimatization}

After successful production of sufficient roots, in vitro rooted plantlets of $C$. wendtii were gently taken out from rooting medium and washed carefully with a soft brush in tap water to remove the adhering agar-agar with plant tissue. The plantlets were then transplanted into plastic pots containing a mixture of organic soil and sand (1:1) overlaid with tap water under greenhouse conditions. After 60 days of acclimatization, the survival rate of $C$. wendtii was $90 \%$, and reached a height range of $9-12 \mathrm{~cm}$. Acclimatized plantlets of $C$. wendtii did not show any morphological abnormality when compared to their donor mother plants. Acclimatized plantlets of $C$. wendtii were vigorously growing without any symptoms of diseases even after 60 days of acclimatization (Figures 3A - 3C). Successful acclimatization and field transfer of the in vitro regenerated plantlets have also been reported in Anubias barteri var. nana petite [25]; Cryptocoryne wendtii and Cryptocoryne becketti [7]; Nymphoides indica [26] and Ludwigia repens [27]. Therefore, the protocol established in this study also ensured a rapid and inexpensive rooting, as well as an adequate survival rate of this commercially important species. 
http://wjst.wu.ac.th
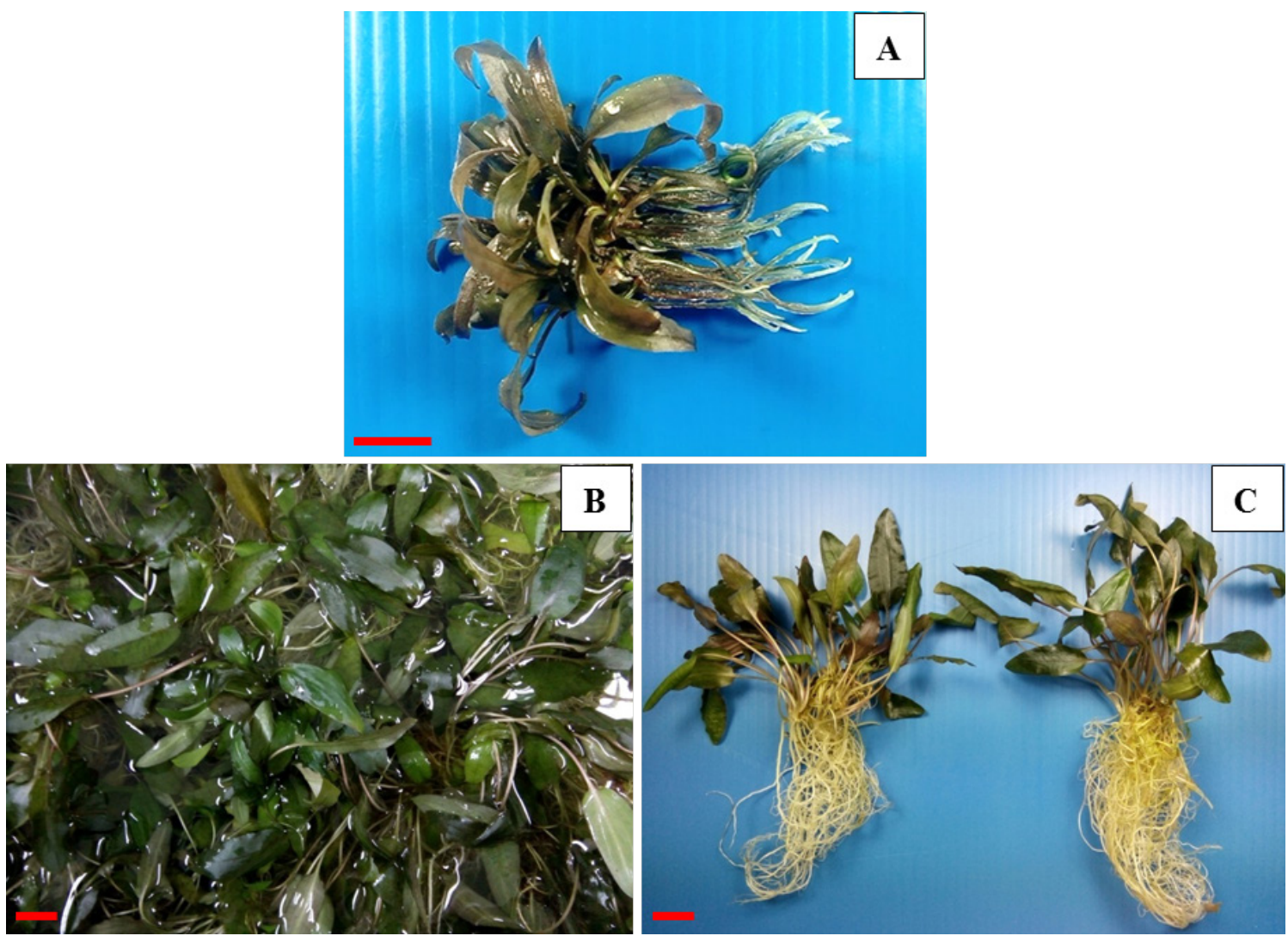

Figure 3 Acclimatization of Cryptocoryne wendtii micropropagated shoots: (A) 45-day-old regenerated shoots on MS medium supplemented with $1.0 \mathrm{mg} / 1 \mathrm{NAA},(\mathrm{B}-\mathrm{C})$ successful establishment of rooted plants in the greenhouse after 60 days of acclimatization. (Scale bar, $\mathrm{A}=2 \mathrm{~cm}, \mathrm{~B}$ and $\mathrm{C}=3 \mathrm{~cm}$ )

\section{Conclusions}

Since $C$. wendtii is a popular ornamental aquatic plant, mass multiplication is essential for preserving this rare species in their natural habitat. We have successfully developed an in vitro regeneration protocol in this study through direct organogenesis using MS medium supplemented with $3.0 \mathrm{mg} / 1 \mathrm{BAP}$. This protocol provides an alternative method with the potential to mass propagate C. wendtii. In conclusions, MS medium supplemented with $3.0 \mathrm{mg} / \mathrm{l} \mathrm{BAP}$ was found to be the best concentration for the induction of Cryptocoryne wendtii direct shoot organogenesis. Up to $100 \%$ of the regenerated shoots formed complete plantlets on a medium containing $1.0 \mathrm{mg} / \mathrm{l} \mathrm{NAA}$ within 45 days, and $90 \%$ of the regenerated plantlets survived and grew vigorously in greenhouse condition. The protocol described here is efficient and reproducible that provides a rapid technique for mass propagation and multiplication of this $C$. wendtii. Such a protocol would allow for a large-scale propagation to meet commercial needs and to directly conserve this threatened Cryptocoryne species by reducing wild collection. 
http://wjst.wu.ac.th

\section{Acknowledgements}

This research was financially supported by Nakhon Si Thammarat Rajabhat University (Grant No. 027/2561), and Prince of Songkla University, Pattani campus, Pattani, Thailand. The authors would like to thank Department of Technology and Industries, Faculty of Science and Technology, Prince of Songkla University, Pattani campus, for providing the laboratory facilities for this investigation.

\section{References}

[1] T Murashige and F Skoog. A revised medium for rapid growth and bioassays with tobacco tissue cultures. Physiol. Plant. 1962; 15, 473-97.

[2] H Windelov. Aquarium Plants. TFH. Publications, Neptune City, 1987.

[3] R Rataj and TJ Horeman. Aquarium Plants. TFH. Publications, Neptune City, 1977.

[4] ES Sulaiman. 2004, Development of Sterilization Procedures and In vitro Studies of Nymphaea lotus. M.Sc. Thesis. University Putra Malaysia.

[5] R Saini and P Jaiwal. Transformation of a recalcitrant grain legume, Vigna mungo L. Hepper, using Agrobacterium tumefaciens-mediated gene transfer to shoot apical meristem cultures. Plant Cell Rep. 2005; 24, 164-71.

[6] ME Kane, EF Gilman, MA Jenks and TJ Sheehan. Micropropagation of the aquatic plant Cryptocoryne lucens. Hort. Sci. 1990; 25, 687-9.

[7] C Stanly, A Bhatt and CL Keng. An efficient in vitro plantlet regeneration of Cryptocoryne wendtii and Cryptocoryne becketti through shoot tip culture. Acta Physiol. Plant 2011; 33, 619-24.

[8] ME Kane, GL Davis, DB McConnell and JA Gargiulo. In vitro propagation of Cryptocoryne wendtii. Aquat. Bot. 1999; 63, 197-202.

[9] M Micheli, AD Gasperis, F Prosperi and A Standardi. Micropropagation of three species of aquatic plants. Agricoltura Mediterranea (Italy) 2006; 131, 46-51.

[10] RA Dixon and RA Gonzales. Plant Cell Culture: A Practical Approach. $2^{\text {nd }}$ ed. Plant Biology Division. The Samuel Roberts Noblefoundation, USA).

[11] PK Pati, SP Rath, M Sharma, A Sood and PS Ahuja. In vitro propagation of rose: A review. Biotechnol. Adv. 2006; 24, 94-114.

[12] K Yadav, A Aggarwal and N Singh. Evaluation of genetic fidelity among micropropagated plants of Gloriosa superba L. using DNA-based markers-a potential medicinal plant. Fitoterapia 2013; 89, 265-70.

[13] T Gaspar, C Kevers, O Faivre-Rampant, M Crevecoeur, C Penel, H Greppin and J Dommes. Changing concepts in plant hormone action. In Vitro Cell Dev. Biol. Plant. 2003; 39, 85-106.

[14] H Chandra, HSS Sinha, AK Patra, U Das, D Selvaraj, RN Misra and J Datta. Low-latitude mesospheric turbulence investigated using coordinated MST radar and rocket-borne observations from India. J. Geophys Res. 2012; 117, D22109.

[15] HMI Herath, SA Krishnarajah and DSA Wijesundara. Micropropagation of two endemic threatened Cryptocoryne species of Sri Lanka. Trop. Agric. Res. Ext. 2008; 11, 19-24.

[16] J Wang, DM Seliskar and JL Gallagher. Plant regeneration via somatic embryogenesis in the brackish wetland monocot Scirpus robustus. Aquat. Bot. 2004; 79, 163-74.

[17] $\mathrm{T}$ Getu and $\mathrm{T}$ Feyissa. In vitro regeneration of sweet potato (Ipomoea batatas (L.) Lam.) Convolvulaceae, from leaf and petiole explants. Ethiop. J. Biol. Sci. 2013; 11, 147-62.

[18] JM Rawat, B Rawat, A Chandra and S Nautiyal. Influence of plant growth regulators on indirect shoot organogenesis and secondary metabolite production in Aconitum violaceum Jacq. Afr J. Biotechnol. 2013; 12, 6287-93.

[19] AM Taji, WA Dodd and RR Williams. Plant growth regulators in tissue culture. In: Plant Tissue Culture Practice, Armidale, Australia, 1995, p. 55-7.

[20] X Shen, J Chen and M Kane. Indirect shoot organogenesis from leaves of Dieffenbachia cv. Camouflage. Plant Cell Tissue Organ. Cult. 2007; 89, 83-90. 
http://wjst.wu.ac.th

[21] HMI Herath, SA Krishnarajah and DSA Wijesundara. Micropropagation of two endemic threatened Cryptocoryne species of Sri Lanka. Trop. Agric. Res. Ext. 2008; 11, 19-24.

[22] T Sharma, MK Khan, P Misra and PK Shukla. Micropropagation of kinnow through nodal explants. The Biosean 2012; 7, 295-7.

[23] S Zakizadeh, B Kaviani and R Onsinejad. In vitro rooting of amaryllis (Hippeastrum johnsonii), a bulbous plant, via NAA and 2-iP. Ann. Biol. Res. 2013; 4, 69-71.

[24] MJ Oh, HR Na, HK Choi, JR Liu and SW Kim. High frequency plant regeneration from zygoticembryo-derived embryogenic cell suspension cultures of watershield (Brasenia schreberi). Plants Biotechnol. Rep. 2008; 2, 87-92.

[25] GE Sheeja, A Joseph and A Korath. In vitro propagation of an ornamental aquatic plant, Anubias barterii Var. Nana petite. Int. J. Curr. Sci. 2015; 18, 1-12.

[26] MA Jenks, ME Kane and DB McConnell. Shoot organogenesis from petiole explants in the aquatic plant Nymphoides indica. Plant Cell Tissue Organ. Cult. 2000; 63, 1-8.

[27] M Ozturk, KM Khawar, HH Atar, C Sancak and S Ozcan. In Vitro Micropropagation of the aquarium plant Ludwigia repens. Asia Pac. J. Mol. Biol. Biotechnol. 2004; 12, 21-5. 